\title{
RESPON CURAH HUJAN DIURNAL TERHADAP MADDEN-JULIAN OSCILLATION AKTIF DI BENUA MARITIM BERBASIS GSMAP GAUGE-CALIBRATED V7
}

\author{
Diurnal Rainfall Response to Active Madden-Julian Oscillation Over \\ Maritime Continent based On GSMaP Gauge-Calibrated V7
}

\section{Achmad Fahruddin Rais ${ }^{1)^{*}}$, Ahmad Kosasih' ${ }^{2)}$, Soenardi'), Yamin Saleh Saidu ${ }^{3)}$, Sanya Gautami4), Umi Fauziyah")}

\author{
1) Badan Meteorologi Klimatologi dan Geofisika. Jl. Angkasa 1 No.2, Kec. Kemayoran, Kota Jakarta \\ Pusat, DKI Jakarta 10610. \\ 2) Stasiun Meteorologi Jatiwangi. Jl. Letnan Angkat Arzain No.28, Sutawangi, Kec. Jatiwangi, Kabupaten \\ Majalengka, Jawa Barat 45454. \\ 3) Stasiun Meteorologi Maritim Kendari. Jl. Jendral Sudirman No.158, Kp. Salo, Kendari, Kota Kendari, \\ Sulawesi Tenggara 93127. \\ 4) Stasiun Meteorologi Sultan Syarif Kasim II. Bandar Udara Sultan Syarif Kasim II, Pekanbaru, Riau \\ 28288. \\ *E-mail: achmad.rais@bmkg.go.id
}

\begin{abstract}
Intisari
Keberadaan pergeseran puncak curah hujan diurnal (DR) terhadap Madden-Julian Oscillation (MJO) aktif di Maritime Continent (MC) masih diperdebatkan sehingga studi ini bertujuan untuk menginvestigasi perubahan tersebut. Selain itu, intensitas rata-rata dan amplitudo DR juga dikaji dalam penelitian ini berbasis GSMaP Gauge-Calibrated V7. Komposit anomali intensitas rata-rata (Ra), amplitudo (Rax) DR MJO aktif dan perbandingan fase puncak DR MJO aktif terhadap klimatologinya (Pax-Pm) pada periode Desember-Januari-Februari (DJF), Maret-April-Mei (MAM), Juni-Juli-Agustus (JJA) dan September-Oktober-November (SON) digunakan dalam tulisan ini dengan uji-z $80 \%$. MJO aktif berbasis rekonstruksi outgoing longwave radiation (OLR) dari kedua indeks realtime multivariate MJO (RMM). Hasil memperlihatkan bahwa MJO aktif memodulasi peningkatan intensitas rata-rata dan amplitudo $D R$ di lautan dan mempengaruhi pergeseran puncak DR menjadi lebih cepat 1 jam dari klimatologi musimannya.
\end{abstract}

Kata Kunci: Curah Hujan Diurnal, Madden-Julian Oscillation, Realtime Multivariate MJO Index

\begin{abstract}
The occurrence of peak phase shift of diurnal rainfall (DR) to active Madden-Jullian Oscillation (MJO) has been debatable, so this study is aimed to investigate the change. Moreover, the mean and amplitude intensity of DR were also analyzed in this study based on GSMaP Gauge-Calibrated V7. The composite of the mean (Ra) and amplitude (Rax) intensity anomaly of $D R$, and the comparison of $D R$ peak phase during the active MJO to its climatology (Pax-Pm) in the period DecemberJanuary-February (DJF), March-April-May (MAM), June-July-August (JJA), and September-OctoberNovember (SON) were used in the study with the z-test of $80 \%$. The active MJO was based on reconstructed outgoing longwave radiation (OLR) of two real-time multivariate MJO (RMM) indexes. The results showed that active MJO modulated the increased mean and amplitude intensity of DR over the ocean and influenced the DR peak phase shift to be faster than its seasonal climatology by one hour.
\end{abstract}

Keywords: Diurnal Rainfall, Madden-Julian Oscillation, Real-Time Multivariate MJO Index

\section{PENDAHULUAN}

Sebagai hamparan kepulauan terbesar di
ekuator dengan perairan yang menghubungkannya dan perantara Samudera Pasifik dengan Samudera Hindia, Maritime Continent (MC) memainkan peran yang penting dalam mempengaruhi sirkulasi global atmosfer (Yamanaka et al., 2018). Susunan kepulauan tersebut membentuk karakteristik curah hujan diurnal (DR) dengan pola umum amplitudo yang besar terjadi di daratan dan pesisir, tetapi tidak ditemui pada lautan terbuka (Vincent dan Lane, 2017). Secara umum, DR di MC memiliki puncak pada sore hari di daratan dan pagi hari di perairan sekitarnya, meskipun puncak tersebut dapat terjadi saat tengah malam di atas daratan yang lebih besar dan curah hujan maksimum sore hari 
juga ditemukan pada sebagian area lautan (Mori et al., 2004; Zhou dan Wang 2006; Wu et al., 2009; Rauniyar dan Walsh 2011.). Siklus DR memiliki peran sebanyak $80 \%$ terhadap variasi curah hujan total di MC (Peatman et al., 2014). Siklus tersebut juga berpropagasi ataupun stasioner (Teo et al., 2011). Sinyal stasioner tersebut terjadi akibat interferensi (atenuasi) dari sinyal yang berpropagasi dalam arah yang berbeda di sekitar Sumatera bagian utara dan semenanjung Malaya (Sumatera bagian selatan).

Pada skala intraseasonal, Madden Jullian oscilation (MJO) adalah fenomena atmosfer yang paling dominan (Madden dan Julian, 1971). MJO terkait dengan cakupan skala besar perawanan dan konveksi yang berpropagasi dari Samudera Hindia ke Samudera Pasifik dengan periode 3090 (Zhang, 2013). MJO melemah ketika mencapai MC (Oh et al., 2013) dan beberapa kasus MJO tidak berpropagasi melintasi MC sama sekali (Feng dkk., 2015).

Studi terdahulu menunjukan hasil yang saling bertentangan tentang dampak MJO aktif terhadap pergeseran puncak curah hujan diurnal (DR) di atas MC dibandingkan dengan klimatologinya.. Penelitian Rauniyar dan Walsh (2011) menunjukkan bahwa pergeseran puncak DR saat MJO aktif menjadi lebih lambat 2 jam dengan menggunakan data TRMM 3B42 dan 3G68. Lain halnya dengan penelitian Sakaeda et al (2017) dan perbandingan Gambar 3 dan 4 dari penelitian Lu et al., (2019) yang mengindikasikan bahwa tidak ada pergeseran puncak DR saat MJO aktif dengan menggunakan TRMM 3B42.

Untuk menyelesaikan permasalahan di atas, perlu dilakukan kajian ulang mengenai pergeseran puncak DR di MC (Gambar 1) saat MJO aktif dengan mempergunakan curah hujan GSMaP Gauge-Calibrated V7 yang memiliki resolusi spasial $0.1^{\circ}$ dan temporal 1 jam dan lebih baik dari TRMM 3B42 dengan resolusi $0.25^{\circ}$ dan 3 jam serta dikalibrasi dengan curah hujan penakar (Shi et al., 2020). Selain itu, perubahan intensitas rata-rata dan amplitudo juga dianalisis dalam penelitian ini.

\section{METODE}

Secara umum, area penelitian mencakup keseluruhan $\mathrm{MC}$ yang terbentang $89.95^{\circ} \mathrm{BT}$ $165.05^{\circ} \mathrm{BT}$ dan $15.05^{\circ} \mathrm{LU}-15.05^{\circ} \mathrm{LS}$ seperti pada Gambar 1. Dalam mengidentifikasi fase dan magnitudo MJO aktif, penulis menggunakan indeks real-time multivariate MJO (RMM) yang berbasis penelitian Wheeler dan Hendon (2004). Indeks RMM yang digunakan meliputi series waktu dan koefisien spasial yang bersumber dari http://poama.bom.gov.au/project/maproom/RMM/ index.html dengan username dan password yang bisa dimintakan ke pengelola website. Rekonstruksi OLR (OLR') dari dekomposisi empirical orthogonal function mode 1 (EOF1) dan EOF2 dengan mengalikan koefisien spasial (a(s)) dan series waktunya $(\mathrm{c}(\mathrm{t}))$ yang tidak lain adalah RMM1 dan RMM2 dengan persamaan sebagai berikut (Hannachi, 2004),

$O L R^{\prime}=E O F 1+E O F 2$

$O L R^{\prime}(t, s)=a_{1}(s) c_{1}(t)+a_{2}(s) c_{2}(t)$

Kemudian penulis merata-ratakan OLR' $\overline{(\overline{O L R})}$ dengan $\mathrm{c}(\mathrm{t})>1$ sebagai indikasi MJO kuat (Wheeler dan Hendon, 2004) dan mengelompokannya dalam setiap fase MJO $1 \mathrm{~s} . \mathrm{d}$ 8. Untuk memilih fase MJO aktif, penulis memilih berdasarkan nilai negatif $\overline{O L R^{\prime}}$ di atas $\mathrm{MC}\left(90^{\circ} \mathrm{BT}\right.$ $-165^{\circ} \mathrm{BT}$ ) sebagai indikator enhanced convective (Hidayat dan Kizu, 2005).

Data curah hujan yang digunakan adalah curah hujan GSMaP Gauge-calibrated V7 setiap jam dalam milimeter per-jam $(\mathrm{mm} / \mathrm{h})$ pada periode Maret 2014 s.d Agustus 2020 yang didapat dari ftp://rainmap:Niskur+1404@hokusai.eorc.jaxa.jp/ standard/v7/hourly_G/. Periode data hanya 6.5 tahun karena ketersediaan data tersebut mulai Maret 2014. Dari data tersebut, rata-rata $(\mathrm{Rm})$ dan amplitudo (Rmx) musiman yang dikelompokan dalam periode Desember-Januari-Februari (DJF), Maret-April-Mei (MAM), Juni-Juli-Agustus (JJA) dan September-Oktober-November (SON) dihitung. Untuk menganalisis respon intensitas DR terhadap MJO aktif, rata-rata $(\mathrm{Ra})$ (amplitudo (Rax)) seasonal anomali DR di wilayah penelitian dihitung dengan pengurangan komposit intensitas rata-rata (amplitudo) DR saat MJO aktif terhadap $\mathrm{Rm}(\mathrm{Rmx})$ serta dikelompokan dalam fase MJO dan periode DJF, MAM, JJA dan SON seperti penelitian Wheeler et al., (2009).

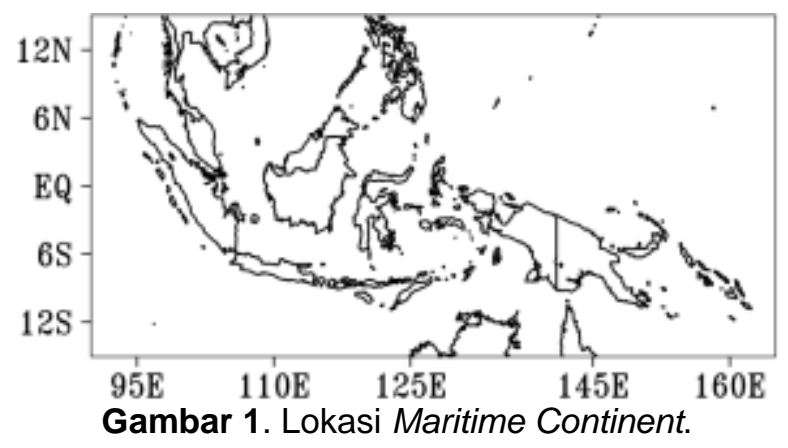

Untuk menganalisis pengaruh MJO terhadap pergeseran puncak DR, fase puncak DR (Pax) saat MJO aktif dikurangin dengan fase puncak rata-rata musiman DR (Pmx). Pergeseran tersebut disimbolkan dengan Pax-Pmx dengan satuan dalam jam (h). Jika pergeseran fase bernilai positif (negatif) maka Pax lebih lambat (lebih cepat) dari Pmx.

Selain itu penulis menghitung signifikansi komposit Rax mempergunakan z-test (Hannemuth, 2013). Batas signifikansi yang digunakan adalah $80 \%$ karena distribusi DR bukanlah distribusi normal (Dan'azumi et al., 2010). 


\section{HASIL DAN DISKUSI}

\subsection{Pemilihan Fase MJO}

Pada Gambar 2, komposit $\overline{O L R^{\prime}}$ yang bernilai negatif pada bujur $89.95^{\circ} \mathrm{BT}$ s.d $110^{\circ} \mathrm{BT}$, $89.95^{\circ} \mathrm{BT}$ s.d $142.5^{\circ} \mathrm{BT}$ dan $112.5^{\circ} \mathrm{BT}$ s.d $165.05^{\circ} \mathrm{BT}$ adalah fase 2, 3 dan 6 dari MJO. Pada fase 4 dan 5 , komposit $\overline{O L R^{\prime}}$ bernilai negatif di atas MC. Sedangkan pada fase 1, 7 dan 8, komposit $\overline{O L R^{\prime}}$ bernilai positif. Hal ini mengindikasikan bahwa MJO pada fase 2 s.d 6 bersifat aktif di atas MC. Ra, Rax dan Pax-Pm yang digambarkan pada Gambar 5-12 mengikuti area MJO aktif tersebut. Tampak pada fase 2 dan 3 untuk MC bagian timur berwarna putih dan MC bagian barat berwarna putih pada fase 6 . Hasil ini juga sejalan dengan Gambar 8 dan 9 pada penelitian Wheeler dan Hendon (2004) yang menunjukkan bahwa anomali OLR saat fase MJO 2-6 berada di MC yang luasan areanya digambarkan pada Gambar 1. Saat fase MJO aktif 2 s.d 6 , ada 605 kejadian di periode DJF, 586 kejadian di periode MAM, 464 kejadian di periode JJA dan 562 kejadian di periode SON.

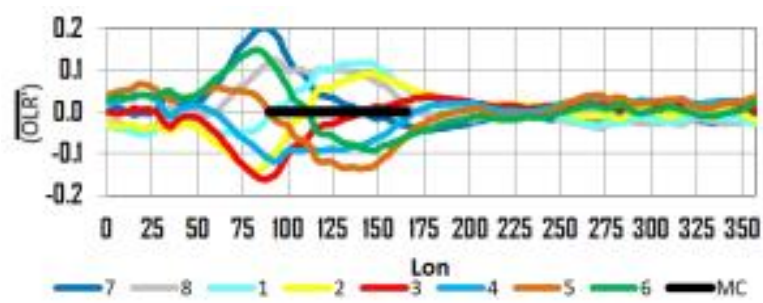

Gambar 2. Grafik komposit $\overline{O L R^{\prime}}$ pada setiap fase MJO

\subsection{Profil Curah Hujan Diurnal Pada Periode DJF, MAM, JJA Dan SON}

Pada Gambar 3, Rm $>0.1 \mathrm{~mm} / \mathrm{h}$ terkonsentrasi di sebagian besar $\mathrm{MC}$ dengan kecenderungan berada di selatan ekuator pada periode DJF dan MAM serta di utara ekuator pada periode JJA dan SON. Distribusi $R m>0.5 \mathrm{~mm} / \mathrm{h}$ dan $R m x>1 \mathrm{~mm} / \mathrm{h}$ umumnya berada di selatan ekuator pada periode DJF kemudian di sekitar ekuator pada periode MAM dan SON. Sedangkan pada periode $\mathrm{JJA}, \mathrm{Rm}>0.5 \mathrm{~mm} / \mathrm{h}$ dan $\mathrm{Rmx}>1$ $\mathrm{mm} / \mathrm{h}$ cenderung tersebar di utara ekuator. Lain halnya di sekitar Papua bagian barat dan selatan, $\mathrm{Rm}>0.5 \mathrm{~mm} / \mathrm{h}$ dan $\mathrm{Rmx}>1 \mathrm{~mm} / \mathrm{h}$ terjadi hampir sepanjang tahun. Hal yang sama juga terjadi pada pesisir barat Sumatera, meskipun melemah pada periode JJA. Pola antisimetrik tersebut menunjukan pengaruh monsoon (Yoden et al., 2017).

Gambar 4 menjelaskan bahwa Pm di daratan dan di lautan tidak banyak perubahan pada semua periode secara umum dengan pola Pm sore sampai malam hari di daratan dan malam sampai siang hari di lautan sekitarnya. Hal yang sama juga dikemukakan dalam penelitian Worku et al., (2019).

\subsection{Pengaruh MJO Aktif Terhadap DR Di Atas MC}

Pada periode DJF (Gambar 5), Ra dan Rax $>1 \mathrm{~mm} / \mathrm{h}$ berada pada area yang sama yang mengindikasikan bahwa MJO bukan hanya meningkatkan nilai rata-rata curah hujan, tetapi juga meningkatkan amplitudonya. Area yang dipengaruhi MJO jauh lebih banyak tersebar di lautan dibandingkan di daratan, $\operatorname{Ra}$ dan $\operatorname{Rax}>1$ $\mathrm{mm} / \mathrm{h}$ juga memiliki pola yang sama. Ra dan Rax $>1 \mathrm{~mm} / \mathrm{h}$ dengan area terbesar tampak berada di sekitar Kepulauan Riau saat fase 2 MJO yang merupakan area borneo vortex (BV) dan semakin melemah saat fase MJO 3-6 sesuai dengan peran MJO yang melemahkan BV (Chang, 2005). Migrasi Ra dari Samudera Hindia sebelah barat Sumatera melalui MC bagian selatan ekuator tampak pada fase MJO 3-6. Hal ini menunjukan bahwa pola musiman masih terlihat dalam fase konvektif aktif MJO seperti yang dikemukakan Wheeler dan Hendon (2004). Area Ra dan Rax $>1$ $\mathrm{mm} / \mathrm{h}$ terdistribusi seimbang baik di MC bagian barat maupun bagian timur. Karena MJO dapat menyediakan kondisi yang sesuai untuk pembentukan dan intensifikasi siklon tropis (Zhang, 2013), fase 5-6 MJO tampaknya memiliki peran tersebut bagi siklon tropis di MC bagian selatan. Jika dibandingkan dengan penelitian Sakaeda et. al (2017) yang membuat tes signifikansi dari koherensi antara OLR terfilter dengan Rax, area signifikansi $80 \%$ Rax (Gambar 5) lebih kecil. Dengan mempergunakan data harian TRMM, Hidayat dan Kizu (2010) juga mendapatkan area signifikansi $95 \%$ anomali curah hujan yang lebih besar.

Lain halnya pada periode MAM (Gambar 6), Ra dan Rax $>1 \mathrm{~mm} / \mathrm{h}$, yang terdampak MJO aktif, memiliki luasan area yang lebih kecil dibandingkan pada periode DJF saat fase MJO 24, tetapi area $R a$ dan $\operatorname{Rax}>1 \mathrm{~mm} / \mathrm{h}$ menjadi lebih luas saat fase MJO 5-6. Area Ra dan Rax $>1$ $\mathrm{mm} / \mathrm{h}$ mulai muncul di utara ekuator, terutama saat fase 4 dan 6 serta memiliki kecenderungan distribusi terbesar di MC bagian timur. Kondisi yang mendukung siklon tropis juga ditimbulkan oleh MJO pada fase 5-6.

Pada Gambar 7, area Ra dan Rax $>1 \mathrm{~mm} / \mathrm{h}$ memiliki luasan yang kecil dan tidak ada area dengan luasan yang besar saat fase 2 MJO dibandingkan periode DJF dan MAM. Saat fase MJO 3, area Ra dan Rax terdistribusi di Selat Karimata dan Laut Cina Selatan bagian selatan serta Filipina bagian selatan sampai Laut Sulawesi. Area Ra bermigrasi ke MC bagian utara yang menyediakan lingkungan kondusif bagi siklon tropis saat fase MJO 4-6. Kecenderungan area konveksi MJO aktif di MC bagian selatan merupakan pola musiman periode JJA seperti dalam penelitian Wheeler dan Hendon (2004). 

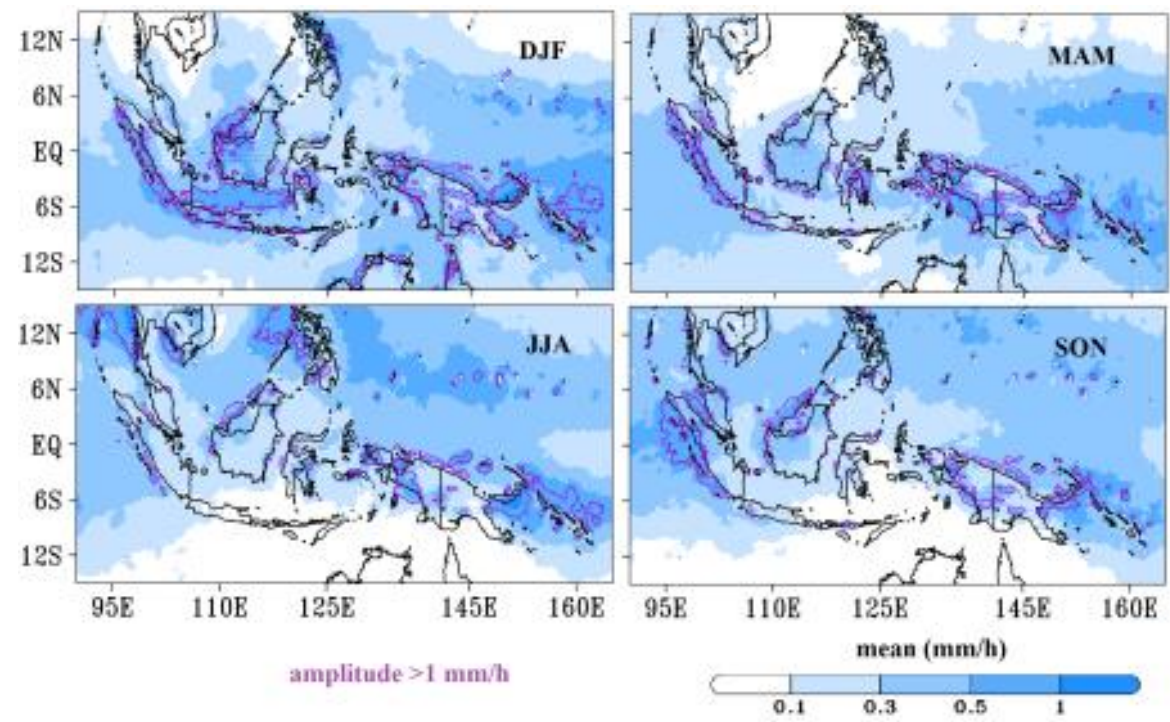

Gambar 3. Rata-rata curah hujan $R m(\mathrm{~mm} / \mathrm{h})$ dan amplitudonya $\mathrm{Rmx}>1 \mathrm{~mm} / \mathrm{h}$ pada periode DJF, MAM, JJA dan SON.

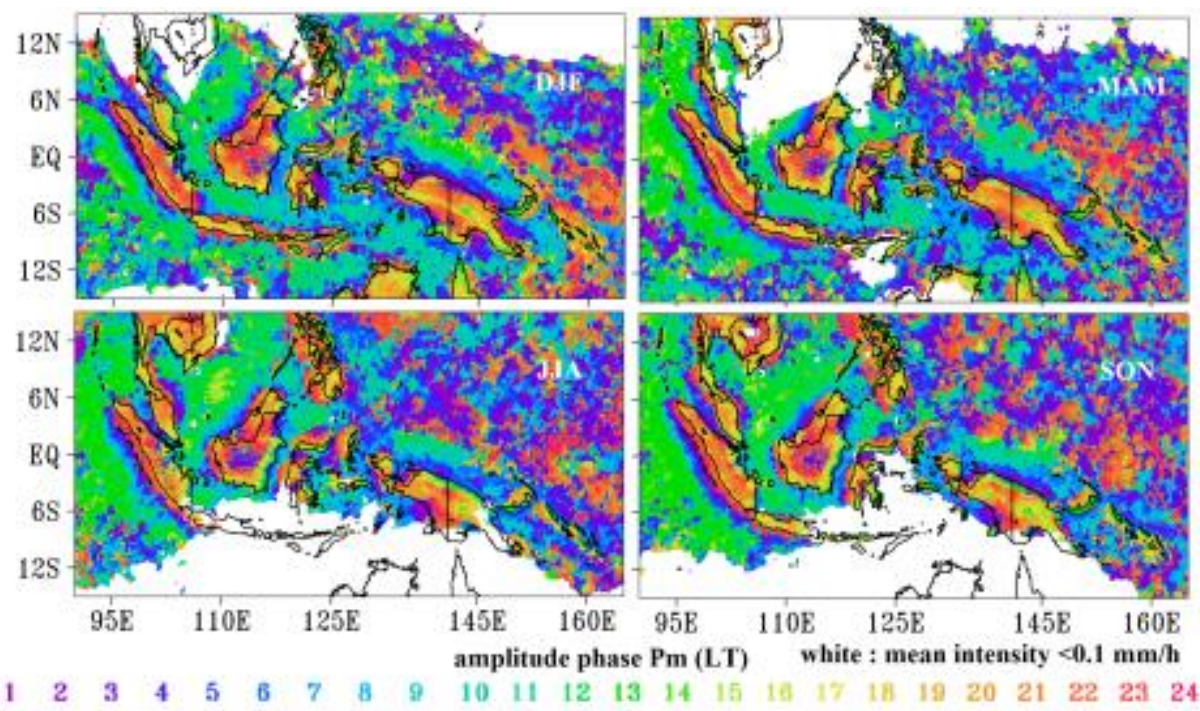

Gambar 4. Fase amplitudo Pm (LT) yang di-mask dengan rata-rata curah hujan $\mathrm{Rm}<0.1 \mathrm{~mm} / \mathrm{h}$ pada periode DJF, MAM, JJA dan SON.

Pada periode SON, area besar RA dan Rax $>1 \mathrm{~mm} / \mathrm{h}$ berada di sekitar perairan barat laut Sumatera dan Laut Cina Selatan bagian selatan yang mendukung terbentuknya BV pada bulan November (Gambar 3 dari Nguyen et. al, 2016). Saat fase MJO 3-4, tidak ditemukan area Ra dan Rax $>1 \mathrm{~mm} / \mathrm{h}$ besar. Sedangkan pada fase 5-6, area $\mathrm{Ra}$ dan $\operatorname{Rax}>1 \mathrm{~mm} / \mathrm{h}$ banyak ditemukan di MC bagian utara. Dibandingkan fase MJO 6 pada periode JJA, area $R a$ dan $R a x>1 \mathrm{~mm} / \mathrm{h}$ lebih besar pada periode SON.

Gambar 5-8 umumnya memperlihatkan bahwa MJO lebih berpengaruh terhadap DR di lautan dibandingkan daratan. Hal ini terjadi karena MJO mengganggu pembentukan seabreeze front yang merupakan sumber utama produksi DR di daratan. (Zhang, 2005).

Pada Gambar 9 periode DJF, MJO yang mengakibatkan Pax dipercepat $1 \mathrm{~h}$ umumnya dan berbeda dengan hasil penelitian Sakaeda et al., (2017) serta Lu et al., (2019) yang mengindikasikan tidak ada pengaruh signifikan MJO terhadap fase DR ataupun Rauniyar dan Walsh yang menyatakan fase DR diperlambat $2 \mathrm{~h}$ dari klimatologinya.

Secara umum pada semua periode (Gambar 9 s.d 12), Pax menjadi lebih cepat $1 \mathrm{~h}$ dari Pmx saat fase MJO 2-6 pada periode DJF, MAM, JJA dan SON. Selain itu, Pax menjadi lebih cepat dari Pmx s.d 6 h sebagai pola dominan ke2 yang tampak dari pergeseran fase tersebut. Ada pula Pax-Pmx yang bernilai positif (Pax lebih lambat dari Pmx) yang nilainya mencapai $6 \mathrm{~h}$, tetapi hanya sebagian kecil. 


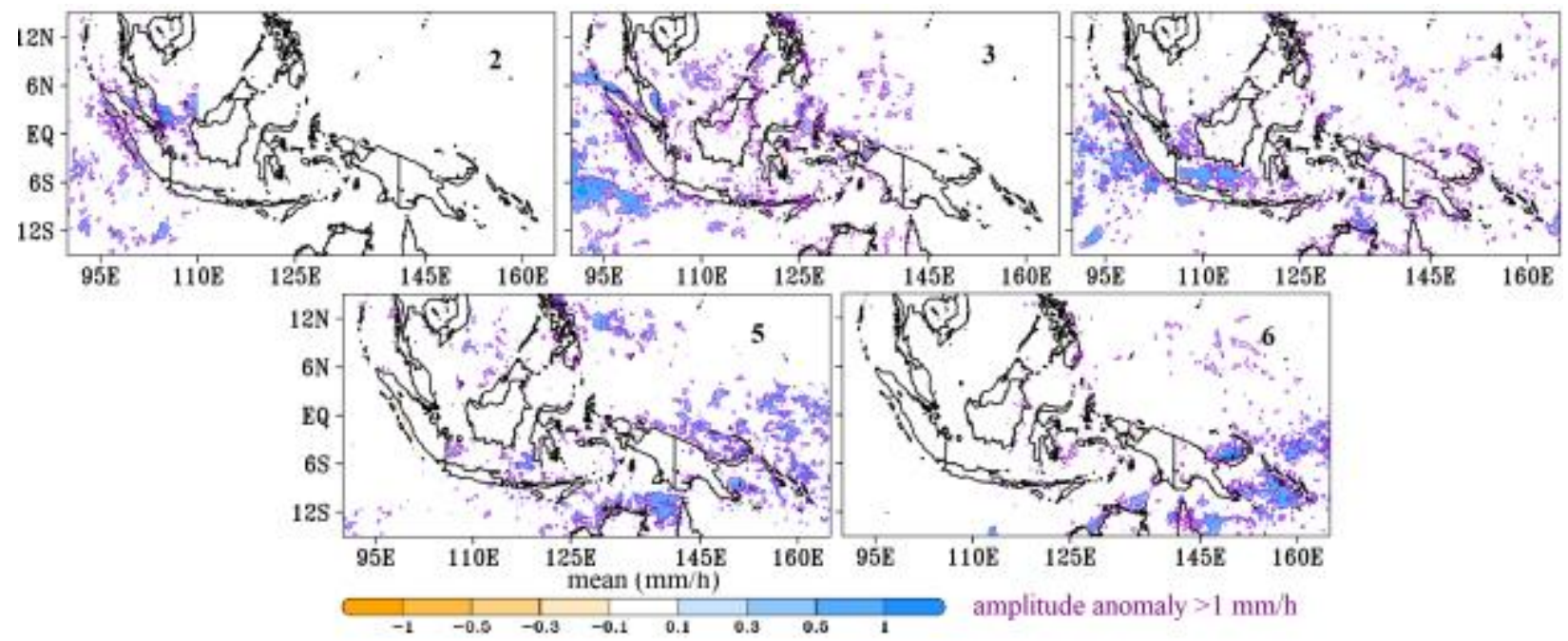

Gambar 5. Rata-rata Ra dan amplitudo Rax anomali curah hujan $(\mathrm{mm} / \mathrm{h})$ fase MJO $2 \mathrm{~s} . d 6$ pada periode DJF. Hanya Ra dan Rax pada signifikansi $80 \%$ dari Rax yang dipetakan.

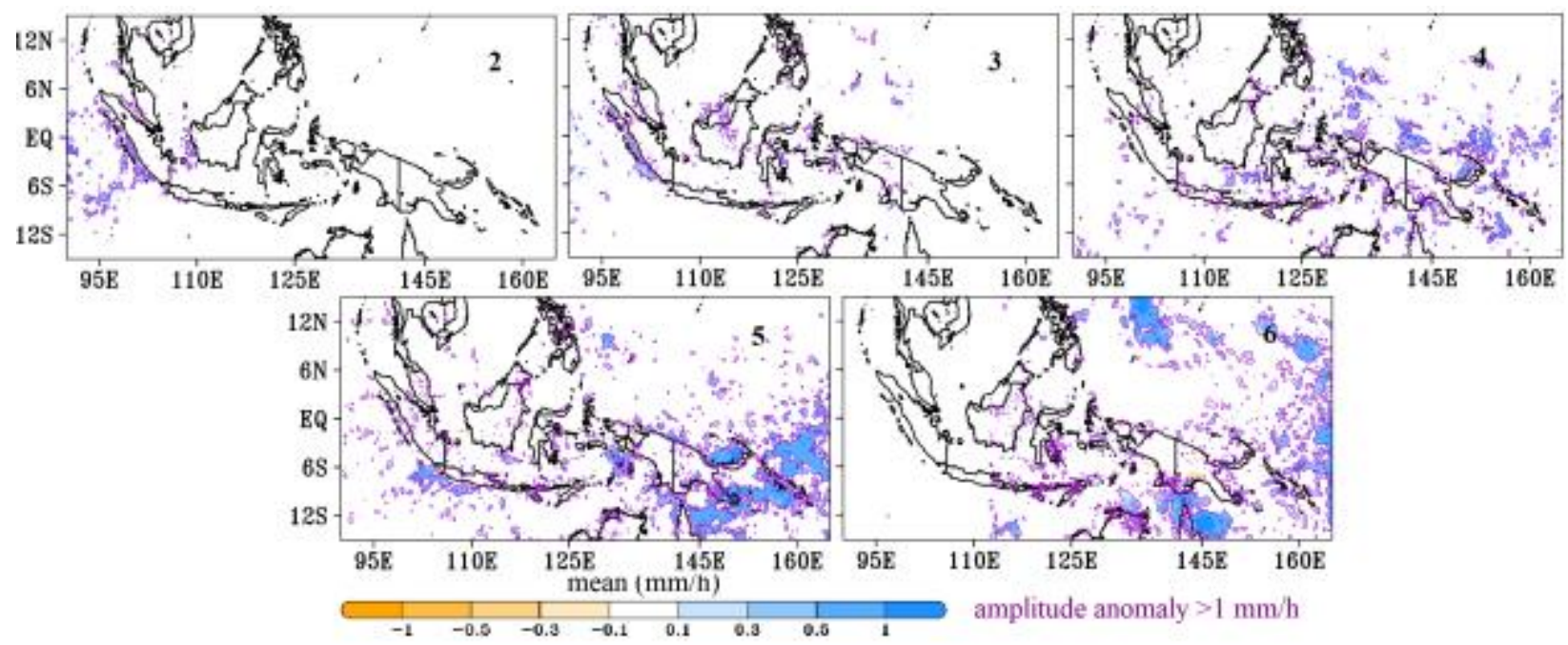

Gambar 6. Rata-rata Ra dan amplitudo Rax anomali curah hujan $(\mathrm{mm} / \mathrm{h})$ fase MJO 2 s.d 6 pada periode MAM. Hanya Ra dan Rax pada signifikansi $80 \%$ dari Rax yang dipetakan.

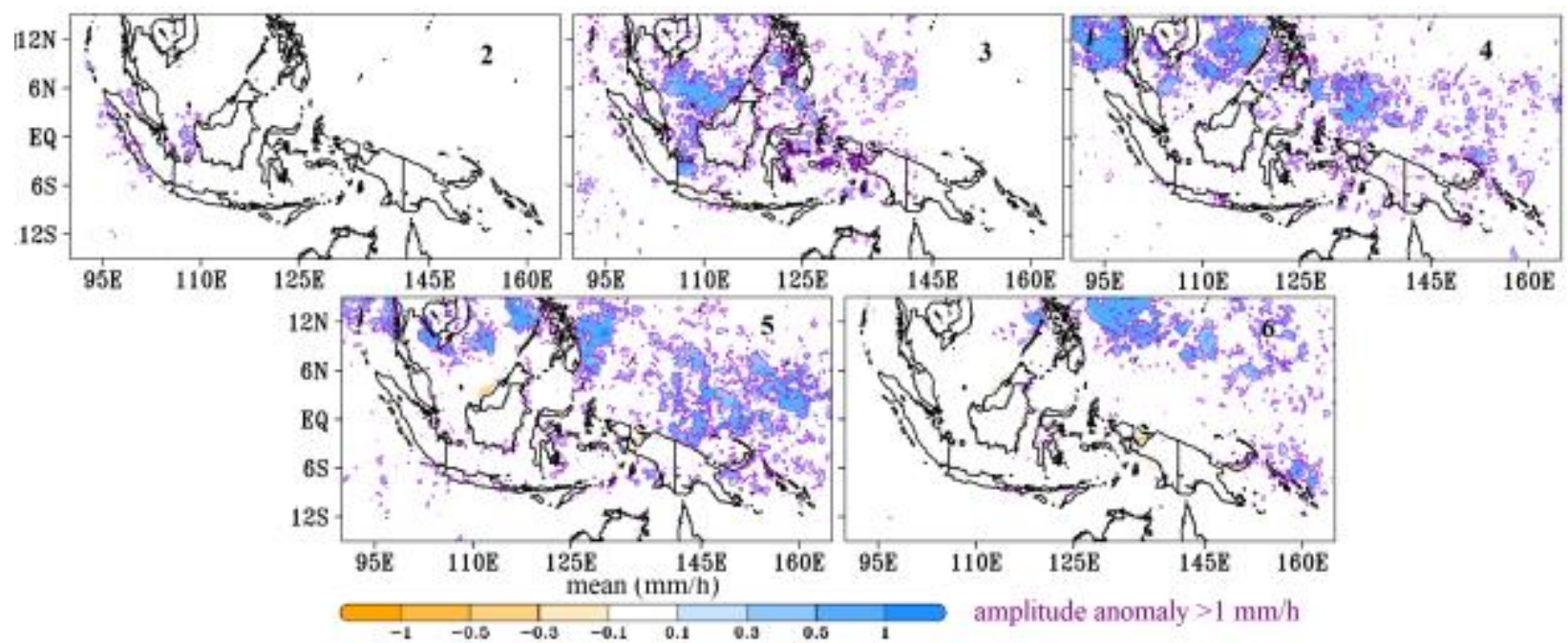

Gambar 7. Rata-rata Ra dan amplitudo Rax anomali curah hujan $(\mathrm{mm} / \mathrm{h})$ fase MJO 2 s.d 6 pada periode JJA. Hanya Ra dan Rax pada signifikansi $80 \%$ dari Rax yang dipetakan. 


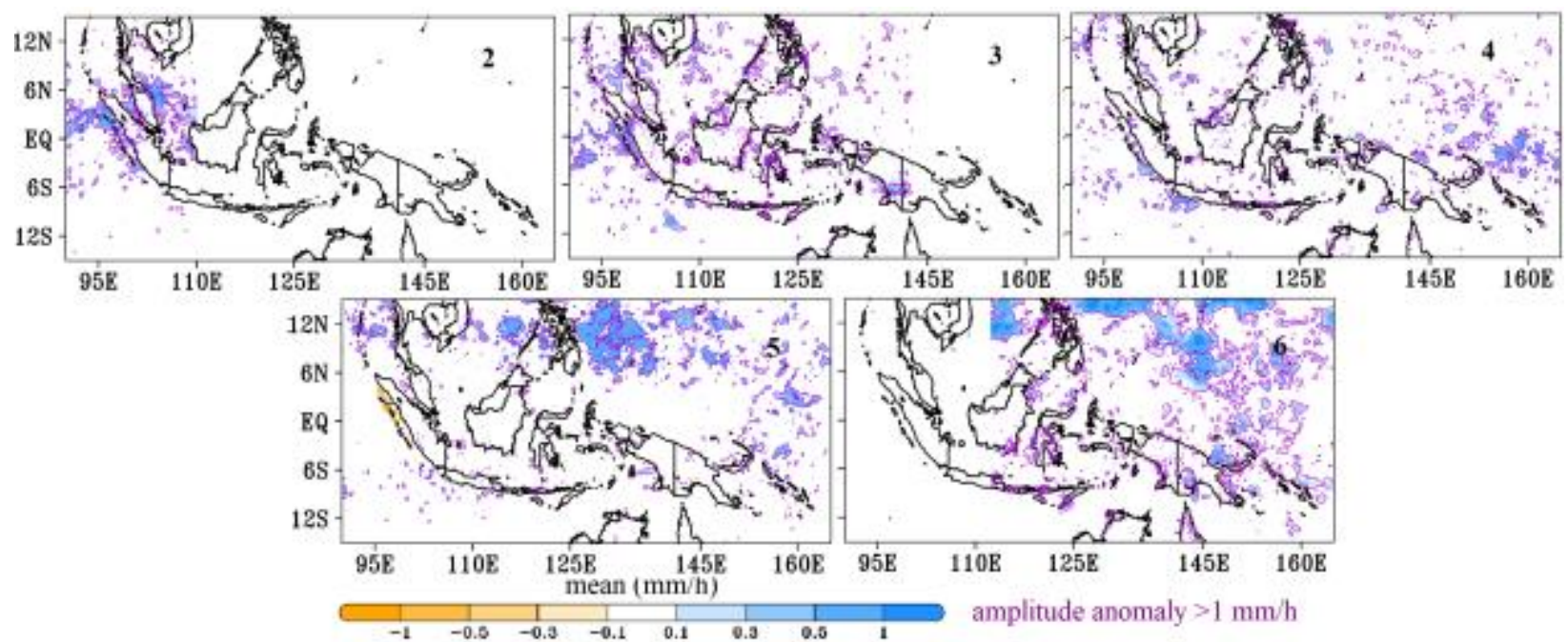

Gambar 8. Rata-rata Ra dan amplitudo Rax anomali curah hujan $(\mathrm{mm} / \mathrm{h})$ fase MJO 2 s.d 6 pada periode SON. Hanya Ra dan Rax pada signifikansi $80 \%$ dari Rax yang dipetakan.

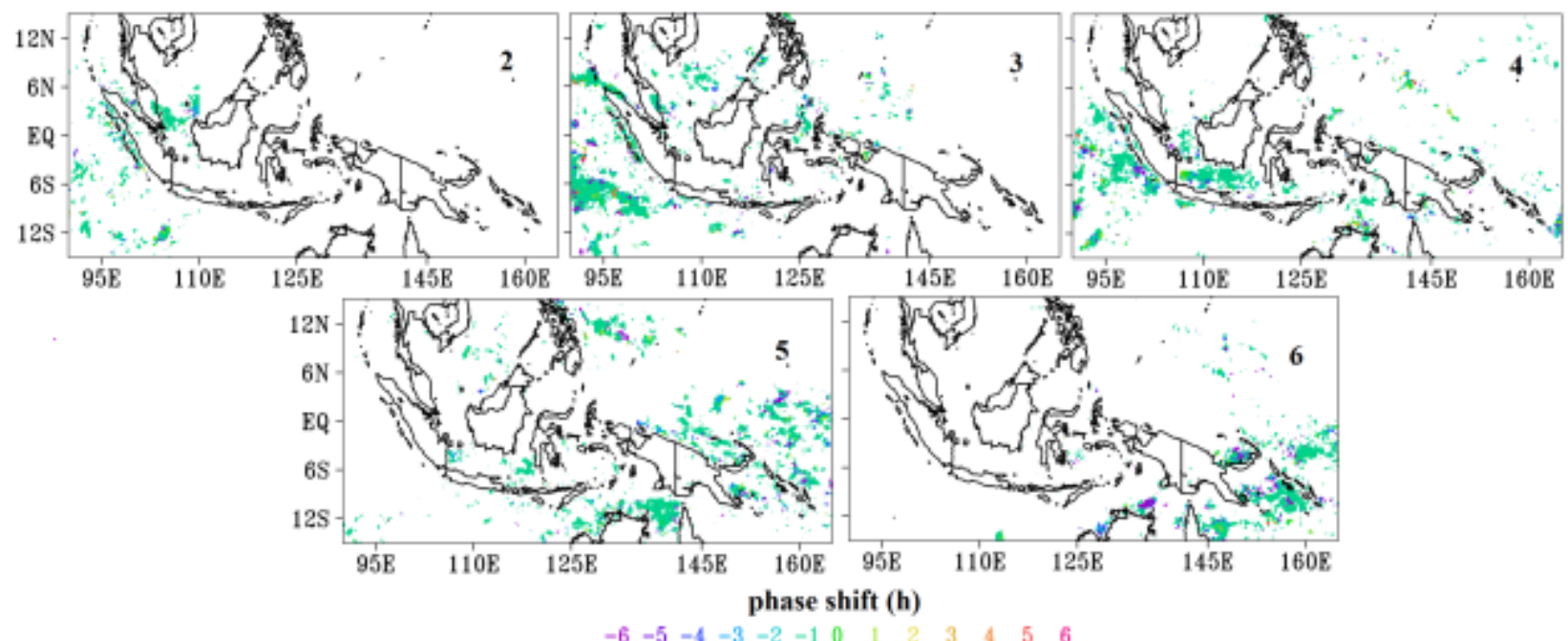

Gambar 9. Pergeseran puncak DR (Pax-Pm) dengan satuan jam (h) yang di-mask dengan signifikansi $80 \% \operatorname{Rax}<1 \mathrm{~mm} / \mathrm{h}$ saat fase MJO $2 \mathrm{~s} . \mathrm{d} 6$ pada periode DJF.

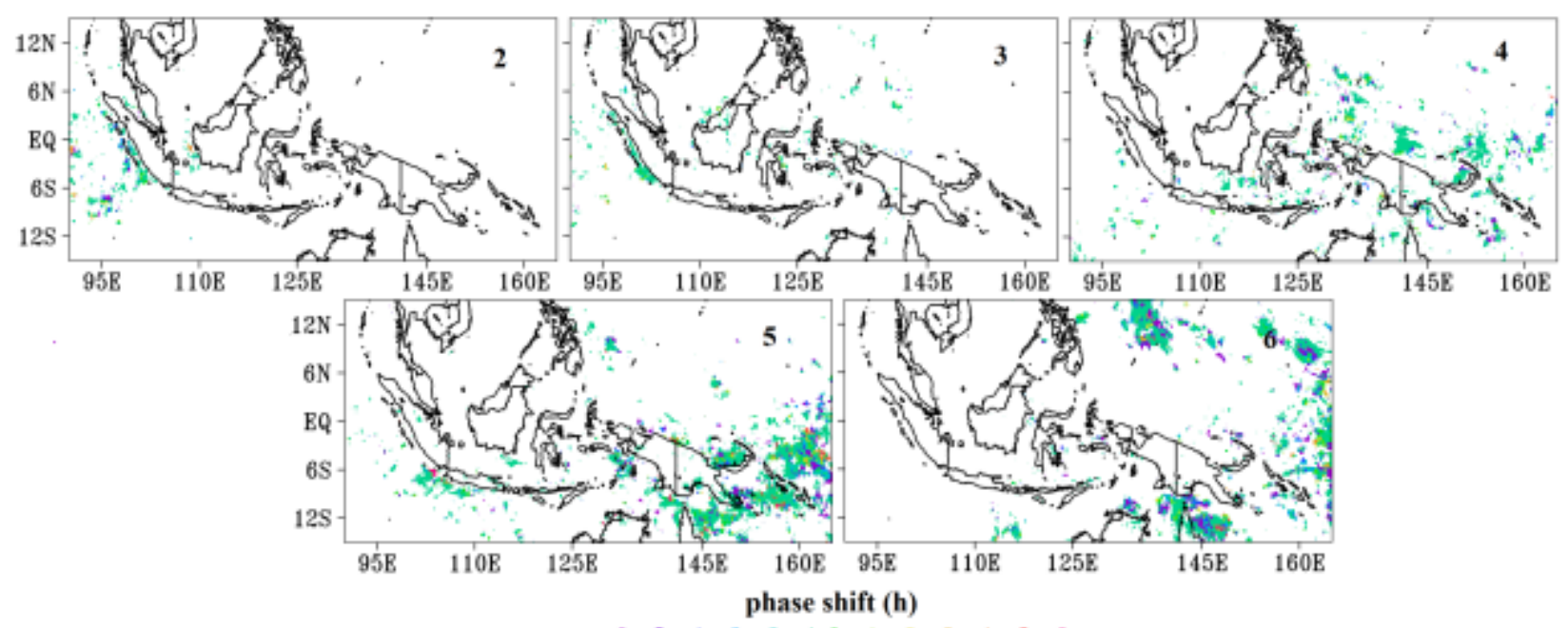

Gambar 10. Pergeseran puncak DR (Pax-Pm) dengan satuan jam (h) yang di-mask dengan signifikansi $80 \% \operatorname{Rax}<1 \mathrm{~mm} / \mathrm{h}$ saat fase MJO 2 s.d 6 pada periode MAM 


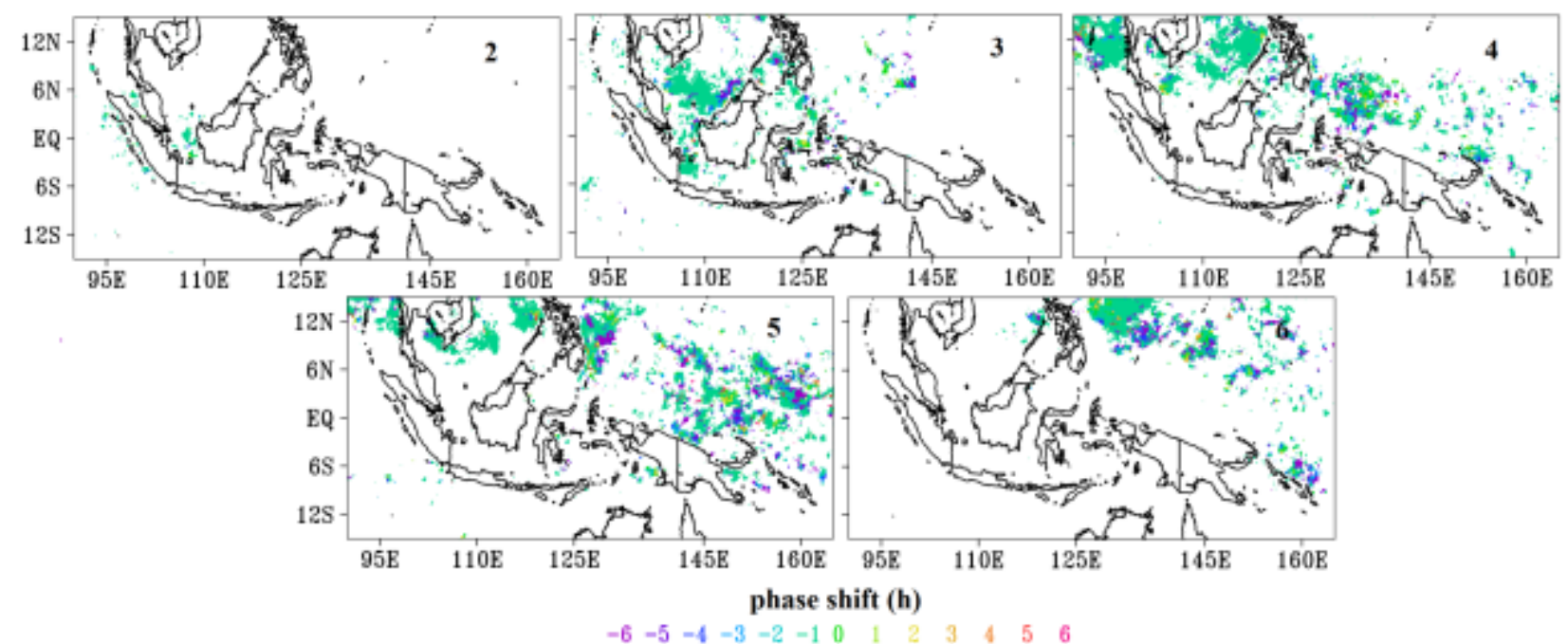

Gambar 11. Pergeseran puncak DR (Pax-Pm) dengan satuan jam (h) yang di-mask dengan signifikansi $80 \% \operatorname{Rax}<1 \mathrm{~mm} / \mathrm{h}$ saat fase MJO $2 \mathrm{~s} . \mathrm{d} 6$ pada periode JJA.

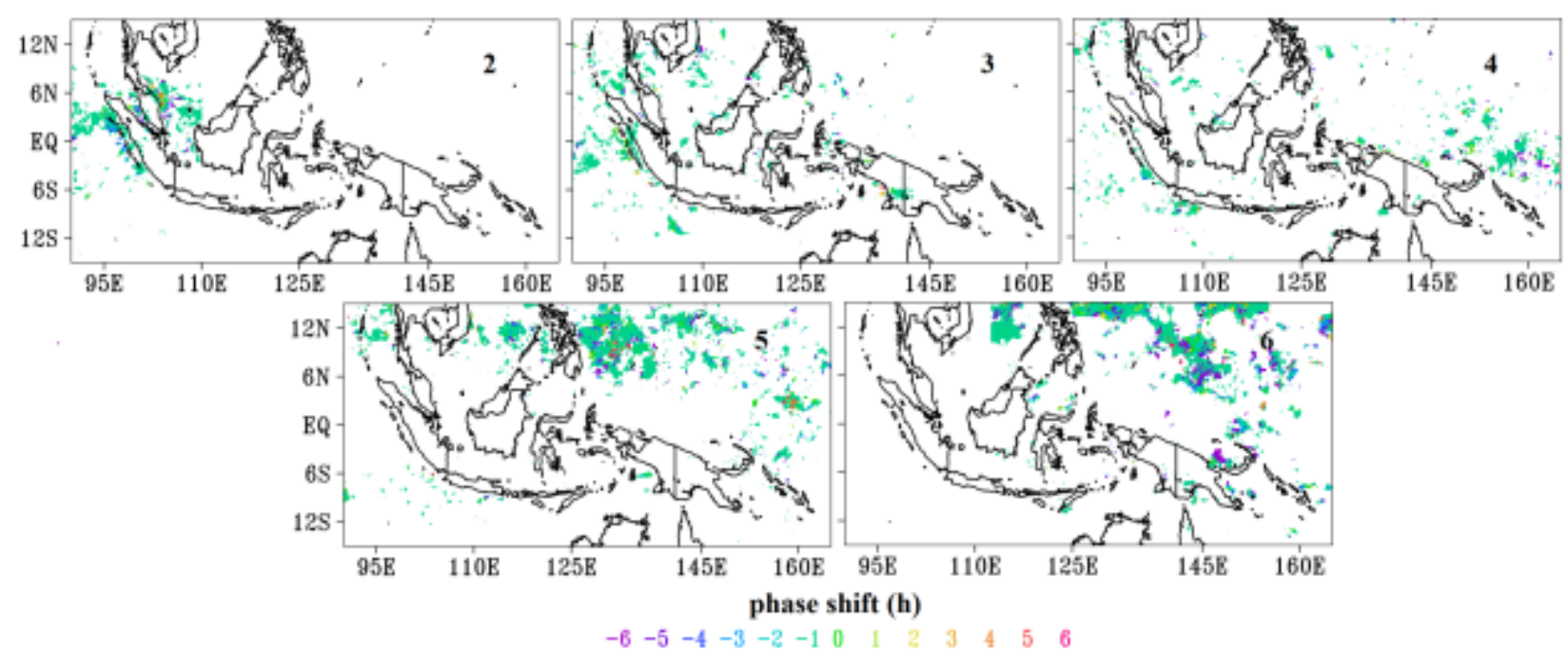

Gambar 12. Pergeseran puncak DR (Pax-Pm) dengan satuan jam (h) yang di-mask dengan signifikansi $80 \% \operatorname{Rax}<1 \mathrm{~mm} / \mathrm{h}$ saat fase MJO $2 \mathrm{~s} . \mathrm{d} 6$ pada periode SON.

\section{KESIMPULAN}

Respon intensitas rata-rata, amplitudo dan pergeseran puncak DR terhadap MJO aktif di MC berbasis curah hujan GSMaP Gauge-calibrated V7 dikaji dalam penelitian ini dengan menganalisis pola komposit anomali intensitas rata-rata dan amplitudo musiman DR serta pergeseran puncak DR saat MJO aktif yang berbasis indeks RMM. Hasil menunjukan bahwa MJO aktif memodulasi peningkatan intensitas dan amplitudo DR di lautan MC pada Gambar 5 s.d 8. Puncak DR juga mengalami pergeseran lebih cepat $1 \mathrm{~h}$ dibandingkan klimatologi musimannya secara umum pada Gambar 9 s.d 12. Dibandingkan penelitian sebelumnya dengan hasil saling bertentangan, hasil penelitian ini mempertegas keberadaan pergeseran puncak DR akibat MJO aktif dengan hasil yang berbeda dari penelitian sebelumnya yaitu menjadi lebih cepat $1 \mathrm{~h}$.

Karena dimensi temporal data yang digunakan hanya 6.5 tahun maka kemungkinan hasil kajian belum mengungkap keseluruhan dampak dinamika MJO aktif terhadap DR di atas $\mathrm{MC}$, sehingga penggunaan data dengan dimensi temporal yang lebih panjang dapat dilakukan pada kajian selanjutnya.

\section{DAFTAR PUSTAKA}

Chang, C. P., Harr, P. A., \& Chen, H. J. (2005). Synoptic disturbances over the equatorial South China Sea and western Maritime Continent during boreal winter. Monthly Weather Review, 133(3), 489-503. doi : 10.1175/MWR-2868.1

Dan'azumi, S., S. Shamsudin dan A. Aris. (2010). Modeling the Distribution of Rainfall Intensity using Hourly Data. American Journal of Environmental Sciences 6 (3): 238-243.

Feng, J., T. Li, dan W. Zhu. (2015). Propagating and nonpropagating $\mathrm{MJO}$ events over 
Maritime Continent. J. Climate, 28, 84308449, doi : 10.1175/JCLI-D-15-0085.1.

Hannachi, A. (2004). A Primer for EOF Analysis of Climate Data. University of Reading

Hidayat, R., dan S. Kizu. (2010). Influence of the Madden-Julian Oscillation on Indonesian rainfall variability in austral summer. Int. J. Climatology., 30, 1816-1825.

Lu, J., Li, T., \& Wang, L. (2019). Precipitation diurnal cycle over the Maritime Continent modulated by the MJO. Climate Dynamics, 53 (9-10), 6489-6501. doi: 10.1007/s00382-019-04941-8

Madden, R. A., \& Julian, P. R. (1971). Detection of a 40-50 day oscillation in the zonal wind in the tropical Pacific. Journal of the Atmospheric Sciences, 28, 702-708. doi : $10.1175 / 1520-$ 0469(1971)028<0702:DOADOI>2.0.CO;2

Mori, S., Jun-Ichi, H., Tauhid, Y.I., Yamanaka, M.D., Okamoto, N., Murata, F., Sakurai, N., Hashiguchi, H. dan Sribimawati, T. (2004). Diurnal land-sea rainfall peak migration over Sumatera Island, Indonesian Maritime Continent, observed by TRMM satellite and intensive rawinsonde soundings. Monthly Weather Review, 132(8), 2021-2039.

Oh, J.-H., B.-M. Kim, K.-Y. Kim, H.-J. Song, dan G.-H. Lim (2013). The impact of the diurnal cycle on the MJO over the Maritime Continent: A modeling study assimilating TRMM rain rate into global analysis. Climate Dyn., 40, 893-911, doi:10.1007/ s00382-012-1419-8.

Peatman S.C., Matthews A.J dan Stevens DP. (2014). Propagation of the Madden-Julian Oscillation through the Maritime Continent and scale interaction with the diurnal cycle of precipitation. $Q J R$ Meteorol. Soc. 140(680):814-825, . doi:10.1002/qj.2161

Rauniyar SP, Walsh KJE (2011) Scale interaction of the diurnal cycle of rainfall over the Maritime Continent and Australia: influence of the MJO. J Clim 24:325-348

Sakaeda, N., Kiladis, G., \& Dias, J. (2017). The diurnal cycle of tropical cloudiness and rainfall associated with the Madden-Julian Oscillation. Journal of Climate, 30(11), 3999-4020. doi : 10.1175/JCLI-D-160788.1

Shi, J, F Yuan, C Shi, C Zhao, L. Zhang, L Ren, Y Zhu, S Jiang dan Y. Liu. (2020). Statistical Evaluation of the Latest GPM-Era IMERG and GSMaP Satellite Precipitation Products in the Yellow River Source Region. Water 12, 1006; doi:10.3390/w12041006

Teo, C-K, T-Y Koh, J C-F Lo dan B. C Bhatt. (2011). Principal Component Analysis of
Observed and Modeled Diurnal Rainfall in the Maritime Continent. J. of Climate 24 (17) 4662-4465. doi : 10.1175/2011JCLI4047.1

Vincent, C. L., \& Lane, T. P. (2017). A 10-year austral summer climatology of observed and modeled intraseasonal, mesoscale, and diurnal variations over the Maritime Continent. Journal of Climate, 30(10), 3807-3828. doi: 10.1175/JCLI-D-160688.1

Wheeler, M. C., \& Hendon, H. H. (2004). An allseason real-time multivariate MJO index: Development of an index for monitoring and prediction. Monthly Weather Review, 132(8), 1917-1932. doi : 10.1175/15200493(2004)132<1917:AARMMI>2.0.CO;2

Wheeler, M. C., S. Cleland, H. Meinke, dan A. Donald, (2009) Impacts of the Madden Julian Oscillation on Australian rainfall and circulation. J. Climate, 22, 1482-1498.

Worku, L. Y., A. Mekonnen dan C. J. Schreck III. (2019). Diurnal cycle of rainfall and convection over the Maritime Continent using TRMM and ISCCP. Int J Climatol. doi : 10.1002/joc.6121

Wu P, Hara M, Hamada JI, Yamanaka MD, Kimura $F(2009)$ Why a large amount of rain falls over the Sea in the Vicinity of Western Sumatra Island during Nighttime. J App/ Meteor Climatol 48:1345-1361

Yamanaka, M. D., Ogino, S. Y., Wu, P. M., Jun Ichi, H., Mori, S., Matsumoto, J., \& Syamsudin, F. (2018). Maritime Continent coastlines controlling Earth's climate. Progress in Earth and Planetary Science, 5(1), 21. doi : 10.1186/s40645-018-0174-9

Yoden, S., S. Otsuka, N. J. Trilaksono dan T. W. Hadi. (2017). Recent Progress in Research on the Maritime Continent Monsoon, in: The Global Monsoon System: Research and Forecast ( $3^{\text {rd }}$ edition) edited by C. P. Chang, H-C Kuo, N-C Lau, R. H. Johnson, B. Wang and M. C. Wheeler, World Scientific Publishing Co. Pte. Ltd. : Singapore. doi : 10.1142/9789813200913_0006

Zhang, C. (2005). Madden-Julian Oscillation. Reviews of Geophysics, 43(2). doi : 10.1029/2004RG000158

Zhang, C. (2013). Madden-Julian oscillation: Bridging weather and climate. Bull. Amer. Meteor. Soc., 94, 1849-1870, doi:10.1175/ BAMS-D-12-00026.1.

Zhou L, Wang Y (2006) Tropical rainfall measuring mission observation and regional model study of precipitation diurnal cycle in the New Guinean region. J Geophys Res 111:D17104 